\title{
The Classification of the Real-Time Interaction-Based Behavior of Online Game Addiction in Children and Early Adolescents in Thailand
}

\author{
Kongkarn Vachirapanang \\ Technopreneurship and Innovation Management Program \\ Graduate School, Chulalongkorn University \\ Bangkok, Thailand
}

\author{
Sukree Sinthupinyo \\ Faculty of Computer Engineering \\ Chulalongkorn University \\ Bangkok, Thailand
}

\author{
Sakoontip Tuisima \\ Faculty of Computer Engineering \\ Chulalongkorn University \\ Bangkok, Thailand \\ Puntip Sirivunnabood \\ Faculty of Psychology \\ Chulalongkorn University \\ Bangkok, Thailand
}

\begin{abstract}
This paper aims to study actual behaviors of Thai children and early adolescents with different levels of game addiction while playing online games from an angle of the interaction between a user and computer. Real-time interactionbased behavior data from a program agent installed in personal computers in 20 sample houses were screened along with consent given by children and their parents. Collection of data about game-playing periods, frequency, game-playing times, text-based chatting, mouse click and keyboard typing during the game was carried out over two months and four case study in-depth interviews for addicted players and their parents. The results revealed a novel method to classify online game addiction level of children and early adolescents by mouse click and keyboard typing data and also found relationship between the playing data recorded and game addiction risk conditions and risk behaviors as explained in the article.
\end{abstract}

Keywords- online game addiction; classification; intelligent agent; real time.

\section{INTRODUCTION}

From the previous research about online game addiction, we found that most researches relating to behaviors and the factors or mechanisms behind game addiction commonly used self-report methodology [1]. But Achab et al.[2] argued that this method may not provide realistic results because respondents may give inaccurate answers to protect themselves. So some researchers attempted to introduce technology as a tool to provide explanatory information during the game such as the measurement of electrodermal activity (EDA) and heart rate (HR) in order to describe the player's experience, cognition and emotions [3, 4], or the real-time emotion diagnosis system which monitor the facial or vocal expressions occurring while playing the game [5].

These are all studies of physically effects on the body when users are playing an online game taking into account mental or psychological conditions. At the same time, Caplan et al.[6] proposed a method which collects and analyzes the data from actual playing periods while playing an online game via the server of the game provider to analyze the relationship between time and problematic Internet use (PIU). In fact, the players interact with their computers not only during the playing period but also with the character controller via basic devices such as the mouse or keyboard as well as playing some online games with an opportunity for conversation via chat room. In previous researches, a relationship was also found between game chat and externalizing aggressive behavior and game addiction $[7,8]$.

Therefore, this research intends to study actual behavior from various interactions between player and computer in the period, time spent, frequency, chat via the keyboard including the amount of mouse clicking and keyboard typing. By comparing children and youths in Thailand with different levels of addiction - Addicted level, High engagement level and Normal level - for defining the behavior patterns which can be used for data evaluation and also to predict and further protect them from game addiction in Thailand.

\section{MATERIALS AND METHODS}

A computer program constructed for collecting data of online game-playing behavior was designed and developed in order to store data consisting of the name of the game, the playing period, frequency, playing time, quantity of mouse click and keyboard typing and also behaviors occurring during play the game such as using harsh or unsuitable words while chatting [9]. Our limitation is that this computer must be regularly used by only one agent; it collected the data of online game-playing behavior based on real-time interaction-based behavior (RTIB) and monitored and recorded the behaviors assigned throughout the period the computer was used, counting units for recording the data as milliseconds, and daily sending all data automatically to the server via the Internet from May - July 2011 as system design shown in Figure 1.

The playing period, frequency, and playing time were analyzed the differentiation values of each addiction level by 
ANOVA and quantity of mouse click and keyboard typing in four game type based on playing characteristics; long term game, casual game, real time game, and turn base game [10].Those data were constructed the user model using Waikato Environment for Knowledge Analysis (WEKA)[11] by features shown in Table 1.Then using 10-fold cross validation method by Decision Tree (DT) and Backpropagation Neural Networks (BNN). For more details, the semi-structure in-depth interviews were conducted with all parents of addicted players.

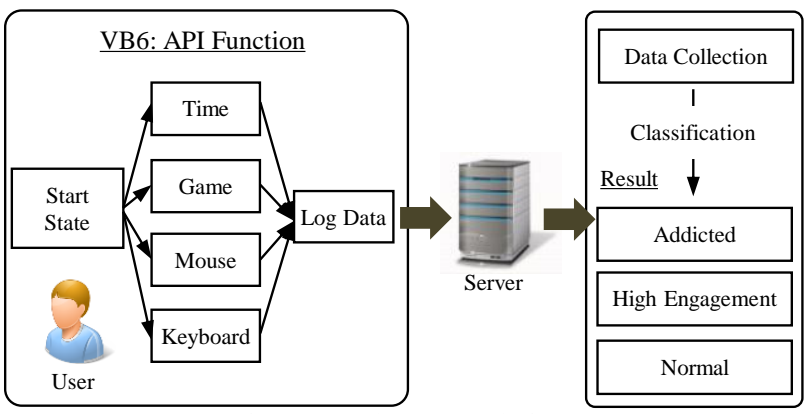

Figure 1. The system design.

TABLE I. FEATURES LIST

\begin{tabular}{|c|c|}
\hline & Features \\
\hline 1) & Weekday or holiday. \\
\hline 2) & Game playing duration per day. (minutes) \\
\hline 3) & Duration of mouse click in game per day. (minutes) \\
\hline 4) & Duration of keyboard pressing in game per day. (minutes) \\
\hline 5) & Total number of mouse click and keyboard pressing in game playing per day. \\
\hline 6) & Total number of mouse click in game playing per day. \\
\hline 7) & Total number of keyboard pressing in game playing per day. \\
\hline 8) & Total number of switching between mouse and keyboard use. \\
\hline 9) & $\begin{array}{l}\text { Maximum number of mouse click before switching to keyboard using in game } \\
\text { playing per day. }\end{array}$ \\
\hline 10) & $\begin{array}{l}\text { Maximum number of keyboard using before switching to mouse click in game } \\
\text { playing per day. }\end{array}$ \\
\hline 11) & $\begin{array}{l}\text { Average time of mouse click and keyboard pressing in game playing per } \\
\text { minute. }\end{array}$ \\
\hline 12) & Average number of mouse click in game playing per minute. \\
\hline 13) & Average number of keyboard using in game playing per minute. \\
\hline 14) & Three computer game addition level; Normal, High engagement, and Addiction \\
\hline
\end{tabular}

\section{RESULTS}

\section{A. Subjects}

By screening and randomizing the sample of children and early adolescents (12- to 14-year-olds) from Thailand who play online games.

All sample stay in Bangkok and are not part of the treatment program for game addiction symptoms and Attention Deficit Hyperactivity Disorder (ADHD). We screen the sample by Game Addiction Screening Test (GAST)[12] of the Center of Game Addiction Prevention at the Institute of Child and Adolescent Ratchanakharin Mental Health,
Department of Mental Health, Ministry of Public Health, Thailand, along with the equipment quality test having a Cronbach's alpha value of 0.804 .

A total of 31 children passed the screen test and consented to be the sample for the collection of data about online gameplaying behavior. After eliminating the player data recorded for less than seven days and the recorded data of more than one player using the same computer, the remaining data were from 20 players classified according to risk level of online game addiction, gender and age, as shown in Table 2.

TABLE II. DE MOGRAPHICS

\begin{tabular}{|l|c|c|c|c|c|}
\hline \multirow{2}{*}{ Addiction Level Quantity by } & \multicolumn{2}{|c|}{ Gender } & \multicolumn{3}{c|}{ Age } \\
\cline { 2 - 6 } & Boy & Girl & $\mathbf{1 2}$ & $\mathbf{1 3}$ & $\mathbf{1 4}$ \\
\hline Normal Level & 10 & - & 2 & 4 & 4 \\
\hline High engagement Level & 6 & - & 2 & 3 & 1 \\
\hline Addicted Level & 3 & 1 & 0 & 2 & 2 \\
\hline \multirow{2}{*}{ Total } & 19 & 1 & 4 & 9 & 7 \\
\cline { 2 - 6 } & \multicolumn{5}{|c|}{$\mathbf{2 0}$} \\
\hline
\end{tabular}

\section{B. Game playing period and frequency}

Table 3 indicates that the average values of the playing periods of all players were: 60.00 minutes $(S D=16.71$ minutes) for the maximum value of time spent per period is the Addicted level player, 53.50 minutes $(\mathrm{SD}=17$. minutes) for the Normal level player and 47.33 minutes $(S D=11.48$ minutes) for the player at High engagement level.

The research defined a weekday as studying day and a holiday as a day off with no studying even in the middle of the week. We checked the parents and each player for the real value. The average value of all level players on holiday was higher than on a weekday.

The results were as follows: the maximum average value on a weekday was from the Addicted level player at 136.75 minutes ( $\mathrm{SD}=56.52$ minutes); from the Normal level player at 87.90 minutes $(\mathrm{SD}=25.66$ minutes); and from the High engagement level player at 85.00 minutes $(\mathrm{SD}=35.52$ minutes).

For the average value on the holiday, we found that the maximum value was from the High engagement level player at 189.33 minutes ( $\mathrm{SD}=65.16$ minutes); from the Normal level player, it was 181.40 minutes ( $\mathrm{SD}=59.69$ minutes); and from the Addicted level, it was 155.25 minutes $(\mathrm{SD}=53.80$ minutes).

Furthermore, the maximum value of game playing per day was on the Addicted level at 132.75 minutes ( $\mathrm{SD}=31.60$ minutes); the High engagement level was 126.66 minutes (SD $=38.68$ minutes); and the Normal level was 126.30 minutes $(\mathrm{SD}=38.11$ minutes).

The average value of playing per week of the High engagement level was the highest value at 601.00 minutes (SD $=270.84$ minutes); the Normal level at 576.30 minutes $(\mathrm{SD}=$ 280.31 minutes) and Addicted level at $572.75 \mathrm{hr}$. (SD = 252.70 minutes).

The average value of game-playing frequency per day of three addiction level players were quite similar at three times per day as shown in Table 3 too. 
TABLE III. DESCRIPTIVE STATISTIC VALUE

\begin{tabular}{|c|c|c|c|c|}
\hline & & $\mathbf{N}$ & Mean & Std. Deviation \\
\hline \multirow{4}{*}{$\begin{array}{l}\text { Time } \\
\text { spent per } \\
\text { period }\end{array}$} & Normal Level & 10 & 53.5000 & 17.36695 \\
\hline & High Engagement Level & 6 & 47.3333 & 11.48332 \\
\hline & Addicted Level & 4 & 60.0000 & 16.71327 \\
\hline & Total & 20 & 52.9500 & 15.56472 \\
\hline \multirow{4}{*}{$\begin{array}{l}\text { Time } \\
\text { spent on } \\
\text { weekday }\end{array}$} & Normal Level & 10 & 87.9000 & 25.66645 \\
\hline & High Engagement Level & 6 & 85.0000 & 35.51901 \\
\hline & Addicted Level & 4 & 136.7500 & 56.52359 \\
\hline & Total & 20 & 96.8000 & 39.62535 \\
\hline \multirow{4}{*}{$\begin{array}{l}\text { Time } \\
\text { spent on } \\
\text { holiday }\end{array}$} & Normal Level & 10 & 181.4000 & 59.69403 \\
\hline & High Engagement Level & 6 & 189.3333 & 65.16032 \\
\hline & Addicted Level & 4 & 155.2500 & 53.80443 \\
\hline & Total & 20 & 178.5500 & 58.46049 \\
\hline \multirow{4}{*}{$\begin{array}{l}\text { Time } \\
\text { spent per } \\
\text { day }\end{array}$} & Normal Level & 10 & 126.3000 & 38.11693 \\
\hline & High Engagement Level & 6 & 126.6667 & 38.68161 \\
\hline & Addicted Level & 4 & 132.7500 & 31.60564 \\
\hline & Total & 20 & 127.7000 & 35.30484 \\
\hline \multirow{4}{*}{$\begin{array}{l}\text { Time } \\
\text { spent per } \\
\text { week }\end{array}$} & Normal Level & 10 & 576.3000 & 280.30898 \\
\hline & High Engagement Level & 6 & 601.0000 & 270.84608 \\
\hline & Addicted Level & 4 & 572.7500 & 252.70718 \\
\hline & Total & 20 & 583.0000 & 258.36958 \\
\hline \multirow{4}{*}{$\begin{array}{l}\text { Playing } \\
\text { frequency } \\
\text { per day }\end{array}$} & Normal Level & 10 & 2.6590 & .97001 \\
\hline & High Engagement Level & 6 & 2.8550 & 1.11783 \\
\hline & Addicted Level & 4 & 2.4650 & 1.22449 \\
\hline & Total & 20 & 2.6790 & 1.01533 \\
\hline
\end{tabular}

TABLE IV. ONE-WAY ANOVA TESTING

\begin{tabular}{|c|c|c|c|c|c|c|}
\hline & & $\begin{array}{c}\text { Sum of } \\
\text { Squares }\end{array}$ & df & $\begin{array}{c}\text { Mean } \\
\text { Square }\end{array}$ & $\mathbf{F}$ & Sig. \\
\hline \multirow{3}{*}{$\begin{array}{l}\text { Time } \\
\text { spent per } \\
\text { period }\end{array}$} & Between Groups & 391.117 & 2 & 195.558 & \multirow[t]{3}{*}{.789} & \multirow[t]{3}{*}{470} \\
\hline & Within Groups & 4211.833 & 17 & 247.755 & & \\
\hline & Total & 4602.950 & 19 & & & \\
\hline \multirow{3}{*}{$\begin{array}{l}\text { Time } \\
\text { spent on } \\
\text { weekday }\end{array}$} & Between Groups & 8011.550 & 2 & 4005.775 & \multirow[t]{3}{*}{3.121} & \multirow[t]{3}{*}{.070 } \\
\hline & Within Groups & 21821.650 & 17 & 1283.626 & & \\
\hline & Total & 29833.200 & 19 & & & \\
\hline \multirow{3}{*}{$\begin{array}{l}\text { Time } \\
\text { spent on } \\
\text { holiday }\end{array}$} & Between Groups & 2950.467 & 2 & 1475.233 & \multirow[t]{3}{*}{.405} & \multirow[t]{3}{*}{.674} \\
\hline & Within Groups & 61984.483 & 17 & 3646.146 & & \\
\hline & Total & 64934.950 & 19 & & & \\
\hline \multirow{3}{*}{$\begin{array}{l}\text { Time } \\
\text { spent per } \\
\text { day }\end{array}$} & Between Groups & 128.017 & 2 & 64.008 & \multirow[t]{3}{*}{.046} & \multirow[t]{3}{*}{.955} \\
\hline & Within Groups & 23554.183 & 17 & 1385.540 & & \\
\hline & Total & 23682.200 & 19 & & & \\
\hline \multirow{3}{*}{$\begin{array}{l}\text { Time } \\
\text { spent per } \\
\text { week }\end{array}$} & Between Groups & 2813.150 & 2 & 1406.575 & \multirow[t]{3}{*}{.019} & \multirow[t]{3}{*}{.981} \\
\hline & Within Groups & 1265528.850 & 17 & 74442.874 & & \\
\hline & Total & 1268342.000 & 19 & & & \\
\hline \multirow{3}{*}{$\begin{array}{l}\text { Playing } \\
\text { frequency } \\
\text { per day }\end{array}$} & Between Groups & .373 & 2 & .187 & \multirow[t]{3}{*}{.165} & \multirow[t]{3}{*}{.849} \\
\hline & Within Groups & 19.214 & 17 & 1.130 & & \\
\hline & Total & 19.587 & 19 & & & \\
\hline
\end{tabular}

Table 4 shown that time spent per period $(\mathrm{F}=0.789$, $p=0.47)$, time spent on weekday $(\mathrm{F}=3.121, p=0.70)$, time spent on holiday $(\mathrm{F}=0.450, p=0.67)$, time spent per day $(0.46$, $p=0.95)$, time spent per week $(\mathrm{F}=0.019, p=0.981)$, and playing frequency per day $(\mathrm{F}=0.165, p=0.85)$ of each addiction level have no significantly different.

\section{Game playing time}

We divided the time in a day into eight periods, with a period of new morning (0.01-6.00a.m.), before entering a study period (6.01-8.00a.m.), morning study period (8.0111.00a.m.) lunch period (11.01a.m.-1.00p.m.), afternoon study period (1.013.30p.m.), after-study period (3.31-6.00p.m.), before-sleeping period (6.01-8.00p.m.) and resting period (8.01-12.00p.m.).

Table 5 shows that most players of all levels have similar behavior patterns for game playing, i.e. on a weekday they play after coming back from school until going to bed, except for some players who play until the following day, i.e. Normal-02 and Addict-02. Some players wake up early in the morning to play before going to school, such as Normal-04, Normal-08, High engagement-01 and High engagement-06.

During online computer game playing in a holiday period shown in Table 6, it is found that there is a distribution of game playing across all periods of the day. Also, it is noticed that there are some players who play until the following morning, especially in a holiday period, i.e. Normal-03, Normal-04 and High engagement-02, while Addict-02 is found playing until the following morning both on a weekday and during a holiday. From these results, it is not possible to conclude that the online computer game-playing times of day of players in each level are different.

TABLE V. PERCENTAGE OF PLAYING FREQUENCY IN EACH PERIOD ON WEEKDAY OF ALL SUBJECTS DIVIDED ACCORDING TO ADDICTION LEVEL

\begin{tabular}{|c|c|c|c|c|c|c|c|c|c|}
\hline \multirow[b]{2}{*}{ Player ID } & \multicolumn{8}{|c|}{ Playing frequency in period of Weekday (\%) } & \multirow[b]{2}{*}{$\begin{array}{c}\text { Total } \\
(\%)\end{array}$} \\
\hline & \begin{tabular}{|c|}
$0.01-$ \\
6.00 a.m.
\end{tabular} & \begin{tabular}{|c|}
$6.01-$ \\
8.00 a.m.
\end{tabular} & \begin{tabular}{|c|}
$8.01-$ \\
$11.00 a . m$.
\end{tabular} & \begin{tabular}{|l|}
11.01 \\
a.m.- \\
1.00 \\
p.m.
\end{tabular} & \begin{tabular}{|c|}
$1.01-$ \\
3.30 p.m.
\end{tabular} & $\begin{array}{c}3.31- \\
6.00 \text { p.m. }\end{array}$ & \begin{tabular}{|c|} 
6.01- \\
8.00p.m.
\end{tabular} & $\begin{array}{l}8.01- \\
12.00 \\
\text { p.m. }\end{array}$ & \\
\hline Normal-01 & - & - & - & - & - & 100.00 & - & - & 100.00 \\
\hline Normal-02 & 1.37 & - & - & - & 2.74 & 8.22 & 21.92 & 65.75 & 100.00 \\
\hline Normal-03 & - & - & - & - & 14.28 & 4.76 & 14.28 & 66.68 & 100.00 \\
\hline Normal-04 & - & 2.80 & - & - & - & - & 31.78 & 65.42 & 100.00 \\
\hline Normal-05 & - & - & - & - & - & - & 30.77 & 69.23 & 100.00 \\
\hline Normal-06 & - & - & - & - & 2.13 & 48.94 & 38.30 & 10.64 & 100.00 \\
\hline Normal-07 & - & - & - & - & - & 8.00 & 44.00 & 48.00 & 100.00 \\
\hline Normal-08 & - & 7.32 & - & - & - & 29.27 & 41.46 & 21.95 & 100.00 \\
\hline Normal-09 & - & - & - & - & - & 5.17 & 37.93 & 56.90 & 100.00 \\
\hline Normal-10 & - & - & - & - & - & 19.23 & 38.46 & 42.30 & 100.00 \\
\hline HE-01 & - & 5.89 & - & - & - & 14.70 & 35.29 & 44.12 & 100.00 \\
\hline HE-02 & - & - & - & - & - & 3.63 & 52.73 & 43.64 & 100.00 \\
\hline HE-03 & - & - & - & - & - & 24.81 & 33.08 & 42.11 & 100.00 \\
\hline HE-04 & - & - & 18.18 & - & - & - & 63.64 & 18.18 & 100.00 \\
\hline HE-05 & - & - & - & - & 7.41 & 7.41 & 37.03 & 48.15 & 100.00 \\
\hline HE-06 & - & 3.84 & - & - & 9.61 & 27.88 & 49.04 & 9.61 & 100.00 \\
\hline Addicted-01 & - & - & - & - & - & 30.51 & 49.15 & 20.34 & 100.00 \\
\hline Addicted-02 & 33.33 & - & - & - & - & 16.67 & - & 50.00 & 100.00 \\
\hline
\end{tabular}




\begin{tabular}{|c|c|c|c|c|c|c|c|c|c|}
\hline Addicted-03 & - & - & - & - & $\mathbf{3 3 . 3 3}$ & 33.33 & 25.00 & 8.34 & 100.00 \\
\hline Addicted-04 & - & - & - & - & - & - & 45.45 & $\mathbf{5 4 . 5 5}$ & 100.00 \\
\hline
\end{tabular}

Note: HE denotes High engagement Level

TABle VI. Percentage Of Playing Frequency In Each Period ON HOLIDAY Of ALl SUBJECTS DIVIDED ACCORDING TO ADDICTION LEVEL

\begin{tabular}{|c|c|c|c|c|c|c|c|c|c|}
\hline \multirow[b]{2}{*}{ Player ID } & \multicolumn{8}{|c|}{ Playing frequency in period of Holiday (\%) } & \multirow[b]{2}{*}{$\begin{array}{r}\text { Total } \\
(\%)\end{array}$} \\
\hline & $\begin{array}{c}0.01- \\
6.00 \mathrm{a} . \mathrm{m}\end{array}$ & \begin{tabular}{|c|}
$6.01-$ \\
8.00 a.m.
\end{tabular} & \begin{tabular}{|c|}
$8.01-$ \\
$11.00 \mathrm{a} . \mathrm{m}$ \\
.
\end{tabular} & $\begin{array}{l}11.01 \\
\text { a.m.- } \\
1.00 \\
\text { p.m. }\end{array}$ & $\begin{array}{c}1.01- \\
3.30 \text { p.m }\end{array}$ & \begin{tabular}{|c|}
$3.31-$ \\
6.00 p.m.
\end{tabular} & $\begin{array}{c}\text { 8.01- } \\
\text { 8.00p.m. }\end{array}$ & $\begin{array}{l}8.01- \\
12.00 \\
\text { p.m. }\end{array}$ & \\
\hline Normal-01 & - & - & - & 66.67 & 11.11 & 22.22 & - & - & \\
\hline Normal-02 & - & 3.53 & 18.82 & 20.00 & 14.12 & 4.71 & - & 38.82 & \\
\hline Normal-03 & 8.89 & 3.33 & 3.33 & 3.33 & 22.22 & 10.00 & 6.67 & 42.22 & \\
\hline Normal-04 & 2.05 & 0.51 & 11.28 & 13.33 & 10.26 & 19.49 & 23.08 & 20.00 & \\
\hline Normal-05 & - & - & 25.00 & 20.00 & 10.00 & 10.00 & 15.00 & 20.00 & 100. \\
\hline Normal-06 & - & - & 12.20 & 17.07 & 26.83 & 4.88 & 36.59 & 2.44 & 100. \\
\hline Normal-07 & - & 11.43 & 31.43 & 17.14 & 17.14 & 8.57 & 2.86 & 11.43 & 100 \\
\hline Normal-08 & - & 11.11 & 25.93 & 14.81 & 18.52 & 11.11 & 14.81 & 3.71 & \\
\hline Normal-09 & - & 2.35 & 2.35 & 7.06 & 30.59 & 10.59 & 17.65 & 29.41 & 100. \\
\hline Normal-10 & - & - & 33.33 & 4.17 & - & 16.67 & 20.83 & 25.00 & \\
\hline HE-01 & - & - & 11.11 & 37.04 & 22.22 & 3.70 & 14.82 & 11.11 & 100. \\
\hline HE-02 & 1.19 & 9.53 & 29.76 & 16.67 & 13.10 & 10.71 & 7.14 & 11.90 & \\
\hline HE-03 & - & 5.19 & 19.48 & 10.39 & 10.39 & 23.38 & 11.69 & 19.48 & 100. \\
\hline HE-04 & - & - & 21.43 & 7.14 & 14.28 & 42.86 & 3.57 & 10.72 & 100.00 \\
\hline HE-05 & - & 2.86 & 4.28 & 20.00 & 17.14 & 31.43 & 12.86 & 11.43 & 100.6 \\
\hline HE-06 & - & 14.28 & 38.89 & 14.28 & 10.33 & 4.76 & 7.94 & 9.52 & 100.00 \\
\hline Addicted-01 & - & - & 11.54 & 26.92 & 21.15 & 13.47 & 9.62 & 17.30 & 100.0 \\
\hline Addicted-02 & 7.14 & 14.29 & 7.14 & 7.14 & 7.14 & 21.43 & 7.14 & 28.58 & 100.00 \\
\hline Addicted-03 & - & - & 13.33 & 33.34 & 20.00 & 20.00 & 13.33 & - & 100.00 \\
\hline Addicted-04 & - & 3.45 & 10.34 & 6.90 & 17.24 & 31.03 & 13.79 & 17.24 & 100.6 \\
\hline
\end{tabular}

Note: HE denotes High engagement Level

\section{Text-based chat during game playing}

Table 7 shows that almost all players have conversations with other players during online computer game playing except Normal-06, Normal-07, High engagement-02, High engagement-04 and High engagement-05. Normal-02, Normal-04 and Normal-05 have conversations both with players they already know and with new players in order to make friends. Most conversations are to do with game matters, five players at Normal level and two players at both of Highengagement and Addicted level; matters of general life are less frequently discussed and only Normal-02, Normal-09 and High engagement- 01 have conversations about studying.

Moreover, it is found three players at Normal level and one player at Addicted level who have rude or violent conversations, i.e. Normal-04, Normal-05, Normal-11 and Addict-03. In the case of Normal-04, conversations concerning pornographic matters have also been found, including requests for sexual relationships with other players. Normal-05 has been found challenging other players they did not know before with severe words. However, from Table 7 we cannot conclude that there is any difference between types of conversation during the online computer game playing of players in all three levels.

TABLE VII. CONVERSATIONS DURING ONLINE COMPUTER GAME PLAYING OF ALL SUBJECTS DIVIDED ACCORDING TO ADDICTION LEVEL.

\begin{tabular}{|c|c|c|c|c|c|c|}
\hline \multirow[b]{2}{*}{ Player ID } & \multicolumn{2}{|c|}{ Conversation with } & \multicolumn{3}{|c|}{ Contents of conversation } & \multirow[b]{2}{*}{$\begin{array}{l}\text { Found rude } \\
\text { or violent } \\
\text { conversations }\end{array}$} \\
\hline & \begin{tabular}{|c|} 
Already \\
know players
\end{tabular} & $\begin{array}{c}\text { New } \\
\text { players }\end{array}$ & $\begin{array}{c}\text { General } \\
\text { life } \\
\text { matters }\end{array}$ & $\begin{array}{l}\text { Studying } \\
\text { matters }\end{array}$ & $\begin{array}{c}\text { Game } \\
\text { matters }\end{array}$ & \\
\hline Normal-01 & - & $\checkmark$ & $\checkmark$ & - & - & - \\
\hline Normal-02 & $\checkmark$ & $\checkmark$ & $\checkmark$ & $\checkmark$ & $\checkmark$ & - \\
\hline Normal-03 & $\checkmark$ & - & - & - & $\checkmark$ & - \\
\hline Normal-04 & $\checkmark$ & $\checkmark$ & $\checkmark$ & - & - & $\checkmark$ \\
\hline Normal-05 & $\checkmark$ & $\checkmark$ & - & - & $\checkmark$ & $\checkmark$ \\
\hline Normal-06 & - & - & - & - & - & - \\
\hline Normal-07 & - & - & - & - & - & - \\
\hline Normal-08 & - & $\checkmark$ & - & - & $\checkmark$ & - \\
\hline Normal-09 & $\checkmark$ & - & $\checkmark$ & $\checkmark$ & - & - \\
\hline Normal-10 & $\checkmark$ & - & - & - & $\checkmark$ & $\checkmark$ \\
\hline $\begin{array}{c}\text { Total in } \\
\text { Normal Level }\end{array}$ & 6 & 5 & 4 & 2 & 5 & 3 \\
\hline HE-01 & $\checkmark$ & - & $\checkmark$ & $\checkmark$ & - & - \\
\hline HE-02 & - & - & - & - & - & - \\
\hline HE-03 & $\checkmark$ & - & - & & $\checkmark$ & - \\
\hline HE-04 & - & - & - & - & - & - \\
\hline HE-05 & - & - & - & - & - & - \\
\hline HE-06 & $\checkmark$ & - & $\checkmark$ & - & $\checkmark$ & - \\
\hline $\begin{array}{c}\text { Total in High } \\
\text { engagement } \\
\text { Level }\end{array}$ & 3 & 0 & 2 & 1 & 2 & 0 \\
\hline Addicted-01 & - & $\checkmark$ & - & - & $\checkmark$ & - \\
\hline Addicted-02 & - & $\checkmark$ & - & - & $\checkmark$ & - \\
\hline Addicted-03 & $\checkmark$ & - & $\checkmark$ & - & - & $\checkmark$ \\
\hline Addicted-04 & - & - & - & - & - & - \\
\hline $\begin{array}{c}\text { Total in } \\
\text { Addicted } \\
\text { Level }\end{array}$ & 1 & 2 & 1 & 0 & 2 & 1 \\
\hline
\end{tabular}

Note: HE denotes High engagement Level

\section{E. Mouse click and keyboard typing}

The agent can be classifying each addiction level players by the data of mouse click and keyboard typing in any game type. Table 8 shown the validation and indicates that a result from DT is higher percentage of classification's accuracy than BNN in case of casual game at 92.63. While the results from $\mathrm{BNN}$ are higher than DT in case of turn base game, real time game, and long term game at 97.73, 90.00, and 97.75 respectively.

TABLE VIII. THE PERCENTAGE OF ACCURACY COMPARISON BY BNN AND DT FOR EACH GAME TYPE IN ANY ADDICTED LEVEL

\begin{tabular}{|l|c|c|c|c|}
\hline \multicolumn{1}{|c|}{ Type of game } & \multicolumn{2}{c|}{$\begin{array}{c}\text { Percentage of } \\
\text { classification's accuracy }\end{array}$} & \multicolumn{2}{c|}{$\begin{array}{c}\text { Percentage of } \\
\text { classification's error }\end{array}$} \\
\cline { 2 - 5 } & BNN & DT & BNN & DT \\
\hline Casual game & 91.35 & 92.63 & 8.65 & 7.37 \\
\hline Turn base game & 97.73 & 90.91 & 2.27 & 9.09 \\
\hline Real time game & 90.00 & 87.50 & 10.00 & 12.50 \\
\hline Long term game & 97.75 & 88.76 & 2.25 & 11.24 \\
\hline
\end{tabular}

\section{F. In-depth Interview with Parents, Self-Report and RTIB of} Addicted Players

Addicted-01: The parents provided information that Addicted-01 uses a computer to play online computer games 
in a private room and they can hear the noise of the games being played all the time. They felt that the child talks or takes part in events with the family less often, although they cannot monitor the other risk behaviors because they did not have enough time to observe the behavior of the child. Table 9 shows the comparison between the risk behavior and its impact according of the Self-Report and the RTIB recorded.

TABLE IX. COMPARISON BETWEEN SELF-REPORT AND RITB OF ADDICTED-01

\begin{tabular}{|l|l|}
\hline \multicolumn{1}{|c|}{ Self-Report } & \multicolumn{1}{c|}{ RTIB } \\
\hline $\begin{array}{l}\text { - Usually play the game without } \\
\text { caring for others as forget homework, } \\
\text { rest, or eating, etc. }\end{array}$ & $\begin{array}{l}\text { - The data showed that playing during } \\
\text { dinner without resting occurred in } 50 \% \text { of } \\
\text { total behavior recorded. }\end{array}$ \\
\hline $\begin{array}{l}\text {-Often play the game for more than } \\
\text { the intended time (two hours per day). }\end{array}$ & $\begin{array}{l}\text {-The data showed that playing more than } \\
\text { two hours per day occurred in 95\% of total } \\
\text { behavior recorded. }\end{array}$ \\
\hline $\begin{array}{l}\text {-There was school absence, because } \\
\text { of playing the game until late, and } \\
\text { cannot wake up. }\end{array}$ & $\begin{array}{l}\text { The data showed that continuous playing } \\
\text { in the evening until 10.00 pm occurred in } \\
30 \% \text { of total behavior recorded. }\end{array}$ \\
\hline
\end{tabular}

Addicted-02: The parents have an agreement with the child about restricting the playing time for online computer games to less than two hours per day. But the child usually plays for longer than the agreement time. The parents usually warn the child to stop playing every day. However, the Addicted-02 accepts the request without any resistance. Regarding the observation by parents, the child often talks with friends about the game, but there were no negative effects or other negative behaviors. The comparison between the behavior which the parents observed, the Self-Report, and the RTIB of Addicted02 is shown in Table 10.

TABLE X. COMPARISON BETWEEN IN-DEPTH INTERVIEW WITH PARENT AND SELF-REPORT AND RITB OF ADDICTED-02

\begin{tabular}{|c|l|l|}
\hline \multicolumn{1}{|c|}{ In-depth Interview } & \multicolumn{1}{|c|}{ Self-Report } & \multicolumn{1}{c|}{ RTIB } \\
\hline $\begin{array}{l}\text { - The children always } \\
\text { play the game more } \\
\text { than the promised time. }\end{array}$ & $\begin{array}{l}\text { - Often play the game } \\
\text { over the intended time. }\end{array}$ & $\begin{array}{l}\text { - The data showed that playing } \\
\text { more than two hours per day } \\
\text { occurred in 67\% of total } \\
\text { behavior recorded. }\end{array}$ \\
\hline- & $\begin{array}{l}\text { - Felt that the } \\
\text { relationship with others } \\
\text { family members is } \\
\text { worse. }\end{array}$ & $\begin{array}{l}\text { - The data showed that using } \\
\text { almost all free time to play the } \\
\text { game occurred in 100\% of the } \\
\text { total behavior recorded. }\end{array}$ \\
\hline
\end{tabular}

Addicted-03: The parents provided the information that previously Addicted-03 played for up to 3-4 hours per day, and there were side effects on many functions as a result. After that, the parents closely controlled playing by setting an agreement with Addicted-03 to play computer games online for no more than 1 hour 30 minutes a day on weekdays and not over 2 hours per day in the holidays. But this was not as successful as it should have been, and some the risk behaviors were still found. Some behaviors that are recorded by the RTIB but which do not appear from the In-depth Interview or Self-Report are shown in Table 11.

Addicted-04: The parents set the playing period at not more than 1 hour 30 minutes a day, but Addicted-04 often could not follow this and greatly lost interest in the other activities. The parents have tried to provide other activities after school in both the weekday and holiday, so the playing time could be decreased. However, after the other activities were completed, the child spent the remaining time playing the game again (see Table 12).

TABLE XI. COMPARISON BETWEEN IN-DEPTH INTERVIEW FROM PARENT AND SELF-REPORT AND RITB OF ADDICTED-03

\begin{tabular}{|c|c|c|}
\hline In-depth Interview & Self-Report & RTIB \\
\hline $\begin{array}{l}\text { - The child always plays } \\
\text { the game more than the } \\
\text { promised time. }\end{array}$ & $\begin{array}{l}\text { - Often play the game } \\
\text { more than the } \\
\text { intended time. }\end{array}$ & $\begin{array}{l}\text { - The data showed that playing } \\
\text { more than the promised time on } \\
\text { weekdays and in holidays } \\
\text { occurred in } 67 \% \text { and } 17 \% \text { of } \\
\text { total behavior recorded. }\end{array}$ \\
\hline $\begin{array}{l}\text { - Found the children play } \\
\text { the game almost all the } \\
\text { time. }\end{array}$ & $\begin{array}{l}\text { - Use almost all free } \\
\text { time to play the game. }\end{array}$ & $\begin{array}{l}\text { - The data showed that using } \\
\text { free time to play the game } \\
\text { occurred in } 100 \% \text { of total } \\
\text { behavior recorded. }\end{array}$ \\
\hline $\begin{array}{l}\text { - Usually play the game } \\
\text { without care for others as } \\
\text { forget school assignment, } \\
\text { and housework. }\end{array}$ & - Less responsibility. & - \\
\hline- & - & $\begin{array}{l}\text { - The data showed that rude } \\
\text { word chatting occurred in 50\% } \\
\text { of total behavior recorded. }\end{array}$ \\
\hline
\end{tabular}

TABLE XII. COMPARISON BETWEEN IN-DEPTH INTERVIEW FROM PARENT AND SELF-REPORT AND RITB OF ADDICTED-04

\begin{tabular}{|l|l|l|}
\hline \multicolumn{1}{|c|}{ In-depth Interview } & \multicolumn{1}{c|}{ Self-Report } & \multicolumn{1}{c|}{ RTIB } \\
\hline $\begin{array}{l}\text { - The child sometimes } \\
\text { plays the game more than } \\
\text { the promised time. }\end{array}$ & $\begin{array}{l}\text { - Often plays the } \\
\text { game more than the } \\
\text { intended time. }\end{array}$ & $\begin{array}{l}\text { - The data showed that playing } \\
\text { more than 1hour 30 minutes per } \\
\text { day occurred in 58\% of total } \\
\text { behavior recorded. }\end{array}$ \\
\hline $\begin{array}{l}\text { - The child uses the } \\
\text { remaining free time from } \\
\text { other activities to play } \\
\text { online games, and cannot } \\
\text { stop playing the game. }\end{array}$ & $\begin{array}{l}\text { - Use almost all } \\
\text { free time to play } \\
\text { the game. }\end{array}$ & $\begin{array}{l}\text { - The data showed that using free } \\
\text { time to play the game occurred in } \\
100 \% \text { of total behavior recorded. }\end{array}$ \\
\hline
\end{tabular}

\section{DISCUSSION}

The study of the game-playing period found three discrepancies with previous researches: 1) The average gameplaying per periods and per week from the sample of the Addicted level were less than the results from the self-report method [13-15]; 2) The average game-playing period per week of the Addicted level player was not higher than the High engagement level player as found in some research [16-18]; 3) The average value on holiday of the Addicted level was not more than on a weekday as Kim et al.[19] have stated.

Besides, when interviewing the parents of the sample group, it showed that some of the sample, especially Addict-04 and 05 , even had a high value of playing behavior on holiday. But agreement between the children and the parents, as well as interest in other activities, may cause a decrease in the playing period on holiday [20], and the playing period per day and week to be lower than ever.

Moreover, the interview with the parents of the sample with the playing period average of higher than 10 hours per week indicated that these players were affected by the various dimensions of online game playing, while Normal-05, 08 and 10 and Addicted-01 had less interest in other activities. Normal-08, Normal-10, High engagement-06 and Addicted-01 spent most of their free time with the game when the relationships between Normal-08, High engagement-03 and High engagement-06 and their families were worse and everybody lost their temper when the parents stopped their 
games. However, the playing period data were unable to indicate the online game addicted condition in the children and adolescents [19], and we should consider this together with the negative consequences that occurred $[21,22]$.

While the above results included the positive relationship between the playing period and game addiction from the previous research $[16,23,24]$, it could be said that the playing period average of higher than 10 hours per week could be an indicator for the risk of game addiction, especially in Thailand.

Furthermore, the next topic is about the frequency and time. We found that the sample played the online game on a weekday from after school (about 3.30p.m.) onwards and had a high value between 8.00 and 12.00 p.m., which is different from the results of Thamawipat and Sawakejun [25], who found that the children from the south of Thailand commonly played the game between 4.00 and 8.00 p.m. This may be caused by the difference in lifestyles between the people in Bangkok and those in the provinces.

In the case of continuous playing through the next day and playing in the morning before class, after the self-report was checked by GAST, and an additional interview with the parents was conducted, and it was found that Normal-02, Normal-03 and Normal-04 were unable to control the playing period and continued playing as they forgot the time. This was similar to High engagement-02 and Addict-02 who always forgot the time and was unable to stop playing when required. Furthermore, Normal-08, High engagement-01 and High engagement-06 were found to play every time except the class that conform to the self-evaluation of always spending their free time on playing the game. Both of the playing tendencies to forget the time and be unable to stop playing when they wanted were indicators of the loss of control that was related with the online game addiction [26-28], including playing from 10.00 to 12.00 p.m. This most affected vulnerable children and adolescents [29], so it can be said that the period of game playing may reflect the risk behavior and lead to loss of control and vulnerability.

The next point is the conversation during the game. The parents of players Normal-04, Normal-05, Normal-10 and Addicted-03 who saw the conversation with harsh or unsuitable words were interviewed and we found that Normal04, Normal-05, Normal-10 and Addicted-03 were easily irritated and felt annoyed. Sometimes they expressed aggressive words or behavior after playing the online game, but Normal-05 did not show such behavior in real life. Chat during the game was a factor which increased the desire of the player to play it [30].

Meanwhile, even though a direct relationship between chat with aggressive words and the game addicted condition was not found, a relationship between aggressive behavior and the online game addicted condition was found [19, 28, 31], so it could be said that following the behavior of the text-based chat in the game can reflect the risk behavior that indicates aggression and relates to the online game addicted condition. Furthermore, the unsuitable risk behavior can be confirmed by what is found in the conversation on sex.
Even this had no direct relationship with the game addicted condition but may affect the lives of children.

The last and very important point is the amount of mouse click and keyboard typing while playing the online computer game. It is an only one result in this paper that can classify an online computer game addiction level of players. Besides, it is a novel method to classify the game addiction level by classification technique in machine learning field. Meanwhile, this method used the real-time interaction-based behavior collected from the interaction between a user and computer while playing games. So, it can reduce errors by the over or underestimate when the children do the addiction screening test by their subjective thinking. At the same time, it can reduce errors from inappropriate behavior observation by the parents that cannot monitor their child all the time. Then, this new addiction classification method can help the parent to have more accuracy data and warning them before their child get into the addiction level.

From the discussion, we can conclude that the development of an intelligent agent could help parents to be aware the addiction level of their children by real-time and more accurate data. The agent can classify not only the addiction level but also shows the risk behavior of self-control, the risk of vulnerability and aggression, and other unsuitable behaviors. Those accuracy real-time data can lead to efficient protection or cure children and early adolescents form the online game addiction disaster.

\section{LIMITATIONS}

It had 20 subjects for this paper then the case studies by semi-structure in-depth interviews of addicted players were conducted for compared with the real-time interaction behaviors. So it may not be used as a general reference but only as a case study and a guideline for further research.

\section{ACKNOWLEDGMENT}

This study was funded by THE 90th ANNIVERSARY OF CHULALONGKORN UNIVERSITY FUND (Ratchadaphiseksomphot Endowment Fund)

\section{REFERENCES}

[1] Kuss, D. and M. Griffiths, Internet Gaming Addiction: A Systematic Review of Empirical Research. International Journal of Mental Health and Addiction, 2012. 10(2): p. 278-296.

[2] Achab, S., et al., Massively multiplayer online role-playing games: comparing characteristics of addict vs non-addict online recruited gamers in a French adult population. BMC Psychiatry, 2011. 11: p. 144.

[3] Drachen, A., Nacke, L.E., Yannakakis, G. and Pedersen A.L., Correlation between heart rate, electrodermal activity and player experience in firstperson shooter games, in Proceedings of the 5th ACM SIGGRAPH Symposium on Video Games2010, ACM: Los Angeles, California. p. 4954.

[4] Kuikkaniemi, K., Laitinen, T., Turpeinen, M., Saari, T., Kosunen, L., and Ravaja, N., The influence of implicit and explicit biofeedback in firstperson shooter games, in Proceedings of the 28th international conference on Human factors in computing systems2010, ACM: Atlanta, Georgia, USA. p. 859-868.

[5] Nosu, K., Kurokawa, T., Korita, H., Ohhazama, Y., and Takeda, H., Real Time Emotion-Diagnosis of Video Game Players from their Facial Expressions and its Applications to Voice Feed-Backing to Game Players. in International Conference on Machine Learning and Cybernetics, 2007. 
[6] Caplan, S., D. Williams, and N. Yee, Problematic Internet use and psychosocial well-being among MMO players. Comput. Hum. Behav., 2009. 25(6): p. 1312-1319.

[7] Holtz, P. and M. Appel, Internet use and video gaming predict problem behavior in early adolescence. Journal of Adolescence, 2011. 34(1): p. 4958.

[8] Moore, R.J., N. Ducheneaut, and E. Nickell, Doing Virtually Nothing: Awareness and Accountability in Massively Multiplayer Online Worlds. Comput. Supported Coop. Work, 2007. 16(3): p. 265-305.

[9] Inrak, P. and S. Sinthupinyo, Applying latent semantic analysis to classify emotions in Thai text. in 2nd International Conference on Computer Engineering and Technology (ICCET), 2010.

[10] Game Genre. [cited 20116 October ]; Available from: http://wiki.thaigamedevx.com/index.php?title=GameGenre.

[11] I. H. Witten, E. Frank, and M. E. Hall, Data Mining: Practical Machine Learning Tools and Techniques. Third Edition ed2011: Morgan Kaufmann Publishers.

[12] Pornnoppadol, C., Sornphaisan, B., Kumkleang, K., and Pattana-amorn, S., Game Addiction Screening Test Development. in The Annual Conference of The Royal College of Psychiatrists of Thailand., 2006. Thailand.

[13] Griffiths, M., A 'components' model of addiction within a biopsychosocial framework. Journal of Substance Use, 2005. 10(4): p. 191-197.

[14] Griffiths, M., Relationship between gambling and video-game playing: a response to Johansson and Gotestam. Psychol Rep, 2005. 96(3 Pt 1): p. 644-6.

[15] Chappell, D., Eatough, V. Davies, M. and Griffiths, M., EverQuest - It's Just a Computer Game Right? An Interpretative Phenomenological Analysis of Online Gaming Addiction. International Journal of Mental Health and Addiction, 2006. 4(3): p. 205-216.

[16] Hsu, S.H., M.-H. Wen, and M.-C. Wu, Exploring user experiences as predictors of MMORPG addiction. Computers \&amp; Education, 2009. 53(3): p. 990-999.

[17] Lee, M.S., et al., Characteristics of Internet use in relation to game genre in Korean adolescents. Cyberpsychol Behav, 2007. 10(2): p. 278-85.

[18] Charlton, J.P. and I.D.W. Danforth, Distinguishing addiction and high engagement in the context of online game playing. Computers in Human Behavior, 2007. 23(3): p. 1531-1548.
[19] Kim, E.J., Namkoon, K., Ku. T., and Kim, S.J., The relationship between online game addiction and aggression, self-control and narcissistic personality traits. Eur Psychiatry, 2008. 23(3): p. 212-8.

[20] Xu, Z., O. Turel, and Y. Yuan, Online game addiction among adolescents: motivation and prevention factors. Eur J Inf Syst, 2012. 21(3): p. 321-340.

[21] Griffiths, M., The Role of Context in Online Gaming Excess and Addiction: Some Case Study Evidence. International Journal of Mental Health and Addiction, 2010. 8(1): p. 119-125.

[22] Skoric, M.M., L.L. Teo, and R.L. Neo, Children and video games: addiction, engagement, and scholastic achievement. Cyberpsychol Behav, 2009. 12(5): p. 567-72

[23] Smahel, D., L. Blinka, and O. Ledabyl, Playing MMORPGs: connections between addiction and identifying with a character. Cyberpsychol Behav, 2008. 11(6): p. 715-8.

[24] Peters, C.S. and L.A. Malesky, Problematic usage among highly-engaged players of massively multiplayer online role playing games. Cyberpsychol Behav, 2008. 11(4): p. 481-4.

[25] Thamwipat, K. and T. Sawakejun. The study of behaviors and effects of internet technology focus on online game exposure by Thai high school students. in 2nd International Conference on Computer Technology and Development (ICCTD), 20102010.

[26] Liu, M. and W. Peng, Cognitive and psychological predictors of the negative outcomes associated with playing MMOGs (massively multiplayer online games). Comput. Hum. Behav., 2009. 25(6): p. 13061311.

[27] Vammen, C. and J. Perkins. An Unobserved Societal Issue, Video Game Addiction in the 21st Century. in IEEE International Symposium on Technology and Society (ISTAS), 2007. 2007.

[28] Mehroof, M. and M.D. Griffiths, Online gaming addiction: the role of sensation seeking, self-control, neuroticism, aggression, state anxiety, and trait anxiety. Cyberpsychol Behav Soc Netw, 2010. 13(3): p. 313-6.

[29] Lemola, S., et al., Habitual computer game playing at night is related to depressive symptoms. Personality and Individual Differences, 2011. 51(2): p. 117-122

[30] Yee, N., Motivations for play in online games. Cyberpsychol Behav, 2006. 9(6): p. 772-5

[31] Charlton, J.P. and I.D.W. Danforth, Validating the distinction between computer addiction and engagement: online game playing and personality. Behav. Inf. Technol., 2010. 29(6): p. 601-613. 